\title{
Young Customers' Atmospheric Factor for Revisit Intention to Theme Restaurants
}

\author{
Aina Mawaddah Adnan, Ammar Yusri, \\ Wan Nazriah Wan Nawawi, Wan Nor Bayah Wan Kamarudin \\ Faculty of Hotel and Tourism Management, \\ Universiti Teknologi MARA (Terengganu), 23000 Dungun, Terengganu, Malaysia \\ wanna035@gmail.com, syadwisy@gmail.com, \\ wanna035@tganu.uitm.edu.my, wnbayah@tganu.uitm.edu.my
}

\begin{abstract}
The rapid emergence of restaurants in the country has leaded the foodservice establishment to grow theme restaurants in competitive market to stay relevant with the trend. Therefore, this study aims to identify the atmospheric factors that influence the young customers' revisit intention into theme restaurants. Quantitative data taken from 200 young customers were analyzed, then, 146 valid questionnaires were returned and the result indicates a statistical relationship between cleanliness and respondents' revisit intention. Thus, restaurateurs need to understand the importance of physical interiors and their influence on overall guest's revisit intentions as a guideline and future references.
\end{abstract}

Keywords: restaurant attributes; restaurateur; theme; young customers

elSSN 2514-7528 @ 2018. The Authors. Published for AMER ABRA cE-Bs by e-International Publishing House, Ltd., UK. This is an open-access article under the CC BY-NC-ND license (http://creativecommons.org/licenses/bync-nd/4.0/). Peer-review under responsibility of AMER (Association of Malaysian Environment-Behaviour Researchers), ABRA (Association of Behavioural Researchers on Asians) and CE-Bs (Centre for EnvironmentBehaviour Studies), Faculty of Architecture, Planning \& Surveying, Universiti Teknologi MARA, Malaysia.

https://doi.org/10.21834/jabs.v3i11.324 


\subsection{Introduction}

Malaysia nowadays is eagering to experience a much better eating atmosphere. Usually, upgraded dining establishments' guests will also demand for a complete experience of dining instead of just good food (Yüksel \& Yüksel, 2002). Andersson \& Mossberg (2004) have successfully came out with five factors that give impacts on meal experience, which reflects the cuisine, the interior of the restaurant, services, company and other guests, plus, they have clarified these factors as meal experience's 'satisfiers'. Clearly, there are factors from the atmosphere that influence people to eat out.

Restaurant attribute is one of the essential keys that management should consider in attracting more customers to come to the restaurant. It is a trend nowadays for customers to choose a restaurant that they want to dine in based on environmental issues. Chow et al. (2013) stated that if a restaurant is not cared about the cleanliness of the workplace, this may spoil the customers' appetite.

This may give negative impression in customers' opinions and may influence them to not revisit that particular restaurant. Customers will not be energetic if the environment of the restaurant is too dull or boring. The management should create a restaurant concept to show that they are different and unique from other restaurants. When there is something new in the restaurant, there will be repetitive customers who would enjoy having a meal there. This will help the restaurant to be parallel with the norms of Generation $Y$, which is our generation right now. Customers revisit intentions are important because they are the ones that will generate income for the restaurant. This study focuses more on the atmospheric factors of theme restaurants that triggers their revisit intention.

\subsection{Literature Review}

Atmosphere seemed to be equally material and immaterial. This proves that atmospheric factors have some kind of relationship with revisit intention because it triggers the factors that led to the intention to revisit. Research suggested that there is a direct relationship between physical environment and the outcomes which make premise guests satisfied, which end up revisiting the premise (Chang, 2000; Chebat \& Michon, 2003). This is a strong proof to say that the factors of atmospheric are highly related to revisit intention. Ryu and Jang, (2007) findings supported that ambience affected customers' post-dining behavioral intentions. The atmospheric factors discussed in this study as follows.

\subsection{Restaurant Cleanliness}

The cleanliness of the restaurant is dubbed as a very important criterion when a restaurant guest observes the dining area's quality (Barber \& Scarcelli, 2009; Liu et al., 2009). Klara (2004) stated that $75 \%$ of customers would not come back to a restaurant if the toilet rooms were not clean. In the same article, Amer (2003) discovered at about $74 \%$ of restaurant guests were confident that they will certainly flee from a restaurant if they saw an unclean view. Cleanliness is vital when operating a restaurant. Threevitaya (2003) found that restaurant cleanliness and hygiene were the first factor customers considered when dining out in Thailand. Aksoydan (2007) suggested that food service establishments that failed to 
meet the standards of food hygiene and cleanliness expected by customers would be targeted as having a low quality of service. Therefore, if a restaurant is unaware of its cleanliness, it may lose their customers even before they dine in. However, previous studies found that the used of restaurant cleanliness concepts are not constant (Yoo, 2012). Physical environment such as the interior of the dining area to evaluate restaurant cleanliness are even used in some studies for evaluation (Ryu and Jang 2008). The cleanliness of a restaurant reflects the whole image of the restaurant in Chinese studies (Jang and Liu 2009).

There is limited research that suggests, among the factors that influence the service encounter, cleanliness is vital (Lockyer, 2003; Scarcelli, 2007). The overall cleanliness of the dining room, the employees' appearance (Ryu and Jang, 2008) and the condition of the servers' station can suggest similar conditions that happen in the kitchen. Understanding what customers consider when they evaluate a restaurant's cleanliness can improve store quality easier due to obtain the useful information from prospective customers (Seung, 2012). U.Z.A. Ungku Fatimah et al. (2011) stated that foodservice hygiene is indeed important, and technically, cleanliness was the third most important factor, after food variety and convenient location, that influences consumer selection of restaurant to dine in. Threevitaya (2003) has ranked the factors of customer importance when dining out, and it seemed that she has put hygiene and cleanliness as number one, or as follows: (1) Hygiene and cleanliness, (2) Quality of the food, (3) Taste of the food, (4) Freshness of the ingredients, (5) Value for the money, (6) Price, (7) Service, and (8) Atmosphere of the restaurants. Luckily, we will only consider the cleanliness of the visible areas, including public areas which consists of dining area, washrooms and the exterior part of the restaurant, as restroom cleanliness was also agreed by customers who evaluate the foodservie quality to be an important criterion (Klara 2004; Barber and Scarcelli 2009).

\subsection{Restaurant Ambience}

Restaurant ambience plays an important role in providing customers experience and also potrays the theme or concept of the restaurant. It can't be measured if the customer didn't experience it. Researcher remarks that the characteristic of the intangible background that may affect non-visual senses and have a subliminal effect on consumer is called ambient conditions (Jin, 2015). Even though ambience is not the main part in restaurant's main service, their absence can result in riot of customers (Raajpoot, 2002). Ryu and Jang (2007) found that ambience and one other factor brought significant influences on customers' emotional responses, as a result, will affect customers' intentions after dining. Music is also a part of ambience. In other studies, there is another important part of the restaurant atmosphere that influences customers, known as music (Areni 2003; Wilson 2003). A suitable music can increase sales (Mattila \& Wirtz, 2001). Music can make an atmosphere special, but if it is not match with the restaurant style, it may downgrade the experience of a meal. Meanwhile, creating good lighting is essential in order to create people's perceptions of the environment (Lin, 2004). This shows that light rays are also affecting customers indirectly. Yet, scent is the most powerful criterium of ambience. Pleasant scents have appeared as a strong determinant for sales increase, and has gained retail businesses' attention (Chebat et al., 2009; Magnini \& Parker, 2009). In addition, the desire of customers to make a purchase 
can be affected by the aroma.

According to Horeco (2000), a simple decoration can give restaurants a competitive advantage. As a customer, we can feel it when the ambience of a restaurant is lacking. Foodservice providers should also take this matter into their favourable consideration. They should check any teensy bit of their restaurant environment to see and evaluate their ambience effectiveness, even from their menu card. Hence, restaurant operators should take good care of the restaurant ambience at a specific level of quality and improve it consistently in time to make customers satisfied (Omar, M. S., Ariffin, H. F., \& Ahmad, R., 2014), and may influence revisit intention.

Besides that, in order to attract more customers as well as encouraging their loyalty, restaurants placed a significant importance on ambience (Ha and Jang, 2010; Reimer and Kuehn, 2005; Raajpoot, 2002; Ryu and Han, 2010; Turley and Milliman, 2000; Wall and Berry, 2007). Good ambience can attract and enhance customer loyalty and influences the intention to revisit. Ariffin et al. (2011) stated that in order to ensure that the elements of restaurant atmospheric will draw experience to customers, design and layout must be planned and executed and all must be made meticulously. Some areas such as the decoration of restaurant, lightings and restaurant layout needed these attentions. This is very important for the restaurateurs to understand that choosing the interior colors wrongly, plus the music in the background, may bring negative impact on the business (Omar, M. S., Ariffin, H. F., \& Ahmad, R., 2014). Furthermore, although the number of major studies in consumer research that confirmed that ambience may influence customer responses are very limited (Ariffin et al., 2012).The physical environment ambient conditions in some settings of service demands the guests to consume the consumptions of service and eventually gives effects towards attitudes and behaviours to the service provider (Nguyen \& Leblanc, 2002). We can assume that positive ambience brings positive mood for the customers. Wall \& Berry (2007) presumed that even though the quality of food is a bit common, the performance of the ambience and service hugely acknowledges an evaluating customer of some establishments.

\subsection{Restaurant Physical Environment}

Parsa et al. (2005) stated that since the success of a restaurant is critically related to food quality, the excellence of the food alone will not promise anyone about success. "Although the food and the service should be of acceptable quality, pleasing physical surroundings may determine to a large extent of the degree of overall satisfaction and subsequent behavior in the restaurant industry (Ryu et al.,2010)". The physical environment of a restaurant also plays a significant role in successful restaurant operations. Research suggests that ultimately, customer is satisfied by the influence of physical environment (Ryu, 2005). Physically, the environment is a vital implication of the psychology of the customers and customers' behavior when a service is primarily consumed for hedonic purposes and when the spending of the customers are moderately to long-term periods in places with atmospherics (Ryu \& Jang, 2007). The importance of physical surroundings to create an image and to influence customer is particularly fit for restaurant industry (Raajpoot, 2002; Ryu \& Jang, 2008). In upscale restaurants' cases, restaurant guests might spend more than 2 hours and realized that the 
physical environment consciously and unconsciously before, during, and after the meal. In addition to food and service, pleasant physical setting should determine to a large extent the degree of overall satisfied and loyal customers (Han \& Ryu, 2009; Kim \& Moon, 2009). Spatial layout that makes people feel narrowed may have a straight effect on customer quality perceptions, excitement levels, and indirectly on their revisit intention (Ryu \& Jang, 2007). Physical environment also may generate emotional responses (Han \& Ryu, 2009; Ryu \& Jang, 2007). Since intangible is a definite criteria of service, and customers are required to be present during the process, the perceptions of the overall quality of the service encounter can be affected by the physical environment, which in turn will affect customers' level of satisfaction in the restaurant industry (Brady \& Cronin, 2001; Ryu \& Jang, 2008).

Chang (2000) reported that physical environment had no significant on return intensions in a direct way; rather, its influence was found to be mediated through consumer satisfaction level. Customers are expecting an experience more than just eating, they seek for a memorable dining experience away from their home (Ryu and Han, 2011). Hence, physical environment aspects in this study includes: function and space and design color as one of the major stimulus during dining experience of customers, which lead to a positive behavioral response (Ha and Jang, 2010; Peri, 2006; Namkung and Jang, 2008). Kalra (2001) explains that dining out has become an important activity of customers' lifestyle, thus experienced customers have increased their expectations regardless of quality, good service, well-cooked food and no dirty interiors, while seeking a better value for their money. In addition, Chang (2000) suggested that perceived physical environment was a direct indicator to make a customer satisfied, thereby suggesting that their satisfaction was directly and positively associated with aspects of positive approach behaviors, which we believe will lead to revisit intention.

Physical environment is not just important for customers only. Foodservice providers also need to be aware of the situation first hand. Pratten $(2003 ; 2003)$ states the hospitality personnel must decide on location, décor, seating arrangements, tableware and other material required to deliver the service. Besides that, it is recommended that the restaurant firm provide an interesting environment through the proper layout of table and chair. The furniture placement is important as it may mediate a sense of enclosure, spatial movement, function as walls and communicate visible or invisible edges (Lin, 2004). Rainforest Café and Planet Hollywood made their mark through innovative interior design and décor. Additionally, it can play as an important marketing tool by affecting customer responses such as attitudes, emotions, price perception, value, satisfaction, and behavior (Berry \& Wall, 2007; Liu \& Jang, 2009; Ryu \& Jang, 2007). A recent study undertaken by Chow et al. (2007) investigating restaurant services in the Chinese context reveals that interaction with the physical environment are more important than the outcome quality in predicting service quality for restaurant customers. In order to attract more people and customers, restauranteurs have devoted a lot of focus to the restaurants interior and exterior design (Lee \& Nan, 2013). Foodservice providers have to believe that the physical environment helps to form customers' dining experiences at restaurants business and positively influence in forming satisfied customers (Ryu and Jang, 2008; Liu and Jang, 2009; Ryu and Han, 2010) as well as affect customers' physical movement and comfort (Wall and Berry, 2007). Yüksel \& Yüksel (2002) 
revealed that "service environment" such as seating arrangements, music, decoration, is the critical determinant in shaping customers' behavior. A study was conducted by (Hidayetoglu, Yildirim, \& Akalin, 2012) in which they evaluated the color and lighting independently on the interior of a hospital in order to determine how the variety of these element help people to guide themselves.

\subsection{Revisit Intention}

The customers' notion of intention or intending is basically a subjective matter. It is a fore judgment on how a customer will behave or act in the future. Frequently, it serves as a dependent variable in many service related researches and satisfaction models (Soderlund and Ohman, 2003). Revisit intention is the emotion when customer felt that they want to experience the same service that they had encountered during past visits on certain places. When a customer is satisfied and delighted with the service that they had consumed, there is always an idea that popped up in their mind that says they want to repeat that experience by revisiting the place. Kivela et al. (2000) prepared a very brief model for satisfaction of dining and revisit customers in their study stating that the return probability of customer depends on whether they are satisfied or not. The study's empirical results indicating that customer satisfaction with the theme restaurant attributes, food quality and atmosphere, were influential in determining customer's return intention $(\mathrm{Ng}, 2005)$. Yet, if customers want to revisit a restaurant, they must have their own reasons (Soriano, 2002). It may be the pressure of work, family issues, lifestyles, and monetary condition, either way, it is still unpredictable. Of course, to know them, we have to put that question in our questionnaires. Customers that have positive and memorable experiences from the restaurant may revisit the same restaurant.

Some guest's revisit intentions existed majorly by the efforts regarding promotions in order to recall their agonizing memories and new attraction's disseminated information (Um, Chon, \& Ro, 2006). For the restaurant industry, it is important to understand the attributes which influence customers' decisions to return to a restaurant for another meal (Soriano, 2002). Other than food quality, the restaurant physical environments also affect customers' revisit intention $(\mathrm{Ng}, 2005)$. In addition, Chow, et al (2013) stated that restaurant operators should have their main focus on the effects on the attributes that may influence restaurant customers and their revisit guests for the sake of maximizing the needs and wants of the customers. Apparently, customer affective response may be influenced by restaurant's environment and entertainment and hence influences revisit intention (Kim \& Moon, 2009; Jang \& Namkung, 2009). Proofs from Chaudhry (2007) have proven that revisit customers produce more than twice gross income than new comers. Despite the positive statistic, to receive new customers, it will require efforts almost seven times more just to retain customers (Conklin, 2006).

Customers nowadays are more focusing on the environmental issues when deciding which restaurant to dine in (Sienny \& Serli, 2010). In a good business system, less cost required and highest profit gained is considered as a successful bargain. Requiring new customers needs additional efforts as well as high performances due to new expectations from new buyers. So, revisitors can make a business achieve its target. Since restaurant 
competitions are getting more and more intense, foodservice establishments are pulling strings to attract customers as well as retaining them by needs and wants fulfilments (Chow, et al 2013). This shows that revisit intention has become more and more relevant to be studied by researchers in this era.

\subsection{Methodology}

This study used self-administered questionnaire which adapted from previous research. A total of 200 questionnaires were distributed conveniently throughout young customer and a total of 146 respondents completed the questionnaire properly. The questionnaire was divided into three sections comprises of 45 items. The purpose of the instrument is to examine the respondents' perspectives on the theme restaurant's atmospheric factors. Apart from that, the questionnaires also aim to identify the level of revisit attention by using five likert scales. The study is conducted in Kuantan which also known as the capital city of Pahang. There are five theme restaurants that operated at the heart of the city. The main focus of this study is on atmospheric factors that influence respondent to revisit these five popular theme restaurants in Kuantan.

\subsection{Results}

Frequency distribution of the respondents' rating on atmospheric factors is shown in figure 1 , it can be seen that the respondents rated cleanliness as the most influential factor among other factors with (92\%) followed by physical environment (86\%) and lastly, ambience (79\%). Total of 146 respondents are the young customers between the ages of 18 to 25 years old. Pearson correlation test has been conducted and the result indicates that there is a positive relationship between atmospheric factors and customers' revisit intention with value of 0.663 .

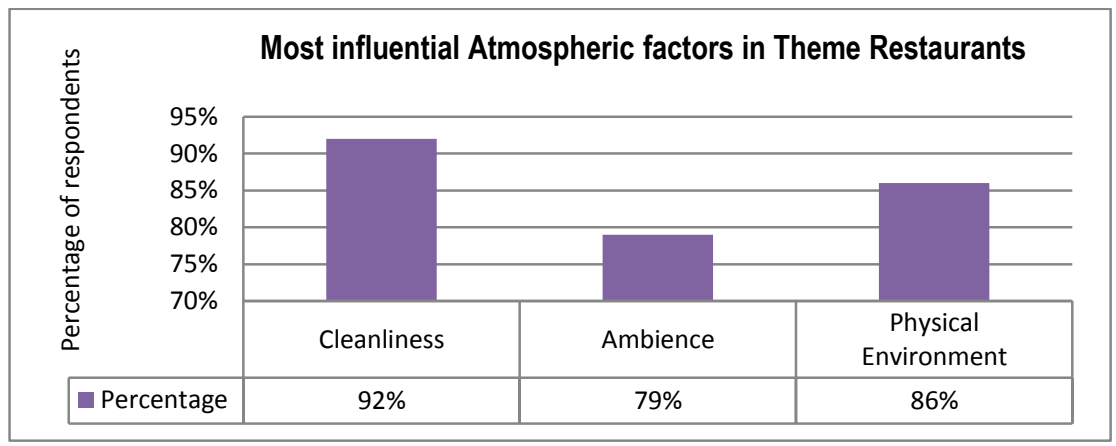

Figure 1: Frequency distribution of atmospheric factors in Theme Restaurants

\subsection{Discussion}

The relationship between atmospheric factors and young customers' revisit intention has 
been immensely discussed in previous studies. However, this study focuses on three factors only, namely; cleanliness, ambiance and physical environment. Customers might be more concerned about the restaurant's environment rather than the food itself (Chow et al, 2013). Bitner (1992) notify that physical environments effect behaviours and create most of the image in the service business such as banks, restaurants, retail stores and hospitals. As the nature of service is supplied and used right away while the customer is on the premises where the service is produced, it cannot be hidden and in fact have a strong impact on consumer's perception of the service experience. Besides that, understanding what customers consider when they evaluate a restaurant's cleanliness can improve store quality easier due to obtain the useful information from prospective customers (Seung, 2012). Cleanliness is very important and needs to be highlighted in the premises regardless of hotel, restaurant or any establishment. In providing the customer with the best experience, the value of cleanliness must be prioritized. Wan Nawawi, W.N et (2018) al examined on theme restaurant: influence of atmospheric factors towards the customers' revisit intention remarks that restaurant cleanliness scored the highest mean with value (M: 4.50) shows that the atmospheric factors have the influence towards customers revisit intention.

\subsection{Conclusion}

The restaurateur should concern about their restaurants' atmospheric factors as it may indirectly affect customers' perception and satisfaction. Atmospheric factors also have influence and have possible impact on customers' revisit intention. Improving the understanding of restaurateurs is crucial by extracting valuable information through survey regarding the atmosphere in sequence to attract concern of customer to stop over in their restaurants. Thus, restaurateurs need to understand the importance of atmospheric factors and their influence on overall guest's revisit intentions as a guideline and future references. Thus, this century will be the start of something new in the service world.

\section{Acknowledgment}

First of all, thanks to Allah SWT for everything that happens during the writing process of this paper. Indeed, we would like to express our thanks to Research Management Unit, Universiti Teknologi Mara Cawangan Terengganu for encouraging us in publications.

\section{References}

Amer, S. (2003), "A sinking feeling", Restaurant Business, Vol. 102 No. 1, p. 84.

Areni CS (2003). Exploring managers' implicit theories of atmospheric music: comparing academic analysis to industry insight. Journal of Services Marketing 17, 161-85.

Andersson, T., \& Mossberg, L. (2004).The dining experience: do restaurants satisfy customer needs. Food Service Technology, 4, $171-177$. 
Ariffin, H.F., Bibon, M.F., \& Abdullah, R.P.S.R. (2011). Restaurant"s atmospheric elements: What the customer wants. Journal of Asian Behavioural Studied, 1(2),33-38.

Ariffin, H. F., Bibon, M. F., \& Abdullah, R. P. S. R. (2012). Restaurant's atmospheric elements:What $\quad$ the customer wants. Procedia-Social and Behavioral Sciences, 38, 380-387.

Aksoydan, E. (2007). Hygiene factors influencing customers' choice of dining-out units:findings from a study of university academic staff. Journal of Food Safety 27(3): 300-316.

Barber, N., \& Scarcelli, J. M. (2009). Clean restrooms: How important are they to restaurant consumers? Journal of Foodservice, 20(6), 309-320.

Berry, L. L., \& Wall, E. A. (2007). The combined effects of the physical environment and employee behavior on customer perception of restaurant service quality. Cornell Hotel and Restaurant Administration Quarterly,48(1), 5969.

Bitner, M. J. (1992). the effect of surroundings on customer and employees. servicescapes,56(2)

Brady, M. and Cronin, J. (2001), "Some new thoughts on conceptualizing perceived service quality: A hierarchical approach", Journal of Marketing, Vol. 65, pp. 34-49.

Chow, K. Y., Dickson Ong, C. S., Tham, W. L., \& Wong, Y. K. (2013). Factors ～influencing dining experience on customer satisfaction and revisit intention among undergraduates towards fast food restaurants (Doctoral dissertation, UTAR).

Chang, K. (2000). The impact of perceived physical environments on customers'satisfaction and return intention. Journal of Professional Services Marketing, 21(2), 75-85.

Chaudhry, P. (2007). Developing a process to enhance customer relationship management for small entrepreneurial business in the service sector. Journal of Research in Marketing and Entrepreneurship, 9(1), 4-23.

Conklin, W. E. (2006). Hans Kelsen on Norm and Language. International Journal of Jurisprudence $\quad$ and Philosophy of Law, 19(1), 101-126.

Chebat, J.C., Morrin, M., \& Chebat, D.R. (2009). Does age attenuate the impact of pleasant ambient scent on consumer response? Environment and Behavior, 41(2), 258-267.

Ha, J. \& Jang, S. (2010). Effects of service quality and food quality: the moderating role of atmospherics in an ethnic restaurant segment. International Journal of Hospitality Management, 29(4), 520-529.

Hidayetoglu, M. L., Yildirim, K., \& Akalin, A. (2012). The effects of color and light on indoor way finding and the evaluation of the perceived environment. Journal of Environmental Psychology, 32(1), 50-58.

Han, H.S., \& Ryu, K. (2009). The roles of the physical environment, price perception, and customer satisfaction in determining customer loyalty in the family restaurant industry. Journal of Hospitality \& Tourism Research, 33(4), 487-510.

Horeco, 2000. La importancia del decorador. Hereco, 171: 111-15.

Jin, Q. (2015). A Research Proposal: The Effects of Restaurant Environment on Consumer Behavior.

Jang, S. and Y. H. Liu. (2009). Perceptions of Chinese restaurants in the US: What 
affects customer satisfaction and behavioral intentions? International Journal of Hospitality Management 28(3): 338-348.

Jang, S. \& Namkung, Y. (2009). Perceived quality, emotions, and behavioural intentions: Application of an extended Mehrabian-Russell model to restaurants. Journal of

Business Research, 62, 451 - 460.

Kivela, J., Inbakaran, R. \& Reece, J. (2000). Consumer research in the restaurant environment; part 3 : Analysis, findings, and conclusions. International Journal of Contem-porary Hospitality Management, 12(1), 13-30.

Klara, R. (2004), "Customer insights: the comfort zone", Restaurant Business, 103(15),14-16.

Kwun, J. W., \& Oh, H. (2006). Past experience and self-image in fine dining intentions. Journal of Foodservice Business Research, 9(4), 3-23.

Kalra, R. (2001). Please please me. Restaurant Business, 100(4), 22.

Kim, W.G., Moon, Y.J. (2009). Customers' cognitive, emotional, and actionable response to the servicescape: A test of the moderating effect of the restaurant 156. type. International Journal of Hospitality Management, 28, 144-

Liu, Y., \& Jang, S. (2009). The effects of dining atmospherics: An extended Mehrabian Russell model. International Journal of Hospitality Management, 28(4), 494-503.

Lockyer, T. (2003). Hotel cleanliness-how do guests view it? Let us get specific. A New Zealand study. International Journal of Hospitality Management, 22(3), 297-305.

Lee, R., \& Nan, L. S.(2013). How the elements of arquitectural design, color, lighting and layout of a QuickService Restaurant Image (QSRI) influences perceived value, customer satisfaction and revisit intentions. Itd, R. (2016). Malaysian Foodservice: The Future of Foodservice to 2016.Researchandmarkets.com. Retrieved 25 March 2016, from http://www.researchandmarkets.com/reports/2207383/malaysian foodservice future of foodservice

Liu, Y., \& Jang, S. (2009). The effects of dining atmospherics: An extended International Journal of Hospitality Management, 28(4), 494-503.

Lin, I.Y. (2004). Evaluating a servicescape: the effect of cognition and emotion. International Journal of Hospitality Management, 23 (2), 163-178.

Magnini, V.P. and E.E. Parker. (2009). The psychological effects of music: implications for hotel firms," Journal of Vacation Marketing, 15(1), 53-62.

Mattila, A. S., \& Wirtz, J. (2001). Congruency of scent and music as a driver of in store evaluations and behavior. Journal of Retailing, 77(2), 273-289.

Namkung, Y. \& Jang, S. (2008). Are highly satisfied restaurant customers really different? A quality perception perspective. International Journal of Contemporary Hospitality Management, 20 (2),142-155.

$\mathrm{Ng}, \mathrm{Y} . \mathrm{N}$. (2005). A study of customer satisfaction, return intention, and word-of mouth endorsement in university dining facilities (Doctoral dissertation, Oklahoma State University).

Nguyen, N., \& Leblanc, G. (2002). Contact personnel, physical environment and the perceived corporate image of intangible services by new clients. International Journal of Service Industry Management, 13, 242262. 
Omar, M. S., Ariffin, H. F., \& Ahmad, R. (2014). Factors affecting customers' satisfaction in Arabic restaurants. International Journal of Administration and Governance, 1(4), 1-8.

Pratten, J. D. (2003). "The importance of waiting staff in restaurant service " British Food Journal, 105 (11), 826-834.

Peri, C. (2006), "The universe of food quality", Food Quality and Preference, 17(3), 3-8.

Parsa, H.G., Self, J.T., Njite, S.D., and King, T. (2005). Why restaurants fail. Cornell Hospitality Quarterly, 46(3), 304-323.

Ryu, K., \& Jang, S. (2007). The effect of environmental perceptions on behavioural intentions through emotions: The case of upscale restaurants. Journal of Hospitality and Tourism Research, 31(1), 56-72.

Ryu, K., \& Han, H. (2010). Influence of physical environment on disconfirmation, customer satisfaction, and customer loyalty for first-time and repeat customers in upscale restaurants.

Ryu, K. (2005). Dinescape, Emotions and Behavioral Intentions in Upscale Restaurants. Kansas State University, Manhattan, Kansas.

Ryu, K. \& Han, H. (2010). Influence of the quality of food, service, and physical environment on customer satisfaction in quick-casual restaurants: moderating role of perceived price. Journal of Hospitality and Tourism Research, 34(3): 310-329.

Raajpoot, N.A. (2002). A multiple item scale for measuring tangible quality in foodservice industry. Journal of Foodservice Business Research, 5, (2), $109 \quad 127$.

Ryu, K. and Han, H., (2011). New or repeat customers: How Does Physical Environment Influence Their Restaurant Experience. International Journal of Hospitality Management, 599-611.

Ryu, K., \& Jang, S. S. (2007). The effect of environmental perceptions on behavioral intentions through emotions: The case of upscale restaurants. Journal of Hospitality \& Tourism Research, 31(1), 56-72. doi:10.1177/1096348006295506.

Ryu, K. and S. Jang (2008). DINESCAPE: A scale for customers' perception ofl dining environments. Journal of Foodservice Business Research, 11(1): 2-22.

Reimer, A., \& Kuehn, R. (2005). The impact of servicescape on quality perception. European Journal of Marketing, 39, 785-808.

Ryu, K., Han, H. and Jang, S. (2010), "Relationships among hedonic and utilitarian values, satisfaction, and behavioral intentions in the fast-casual restaurant industry", Internationl Journal of Contemporary Hospitality Management, 22(3), 416-432.

Sienny, T., \& Serli, W. (2010). The concern and awareness of consumers and food service operators towards food safety and food hygiene in small and medium restaurants in Surabaya, Indonesia. International Food Research Journal, 17, 641-650.

Scarcelli, J. (2007), "Clean restaurant restrooms: do they indicate a clean kitchen?", published Masters thesis, Purdue University, West Lafayette, IN.

Soriano, D. R. (2002). Customers' expectations factors in restaurants: The situation in Spain. International Journal of Quality \& Reliability Management, 19, (8/9), 1055-1067. 
Soderlund, M., and Ohman, N. (2003). Behavioral Intentions in Satisfaction Research Revisited. Journal of Consumer Satisfaction, Dissatisfaction and Complaining Behavior, 16, 53-66.

Seung, A. Y. (2012). Customer perceptions of restaurant cleanliness: A cross cultural study. Unpublished master's thesis, Virginia Polytechnic Institute and State University, Blacksburg.

Turley, L.W., \& Milliman, R. E. (2000). Atmospheric effects on shopping behavior: A review of the experimental evidence. Journal of Business Research, 49(2), 193-211.

Threevitaya, S. (2003). Factors that influenced the decisions of customers to dine at selected restaurants in Bangkok, Thailand (Doctoral dissertation, University of Wisconsin-Stout).

U.Z.A. Ungku Fatimah, H.C. Boo, M. Sambasivan, R. Salleh (2011). Foodservice Hygine Factor- The Consumer Perspective. International Journal of Hospitality Management, 30: 38-45.

Um, S., Chon, K. \& Ro, Y. (2006). Antecedents of revisit intention. Annals of Tourism Research, 33 (4): 1141-1158.

Wall, E.A., \& Berry, L.L. (2007). The combined effects of the physical environment and employee behavior on customer perception of restaurant service quality. Cornell Hotel and Restaurant Administration Quarterly, 48, (1), 59-69.

Wilson S (2003). The effect of music on perceived atmosphere and purchase intentions in a restaurant. Psychology of Music, 31:93-113.

Wan Nawawi, W.N., Wan Kamarudin W.N.B, Mat Ghani, A., Adnan, A. M. Theme Restaurant: Influence of Atmospheric Factors towards the Customers' Revisit Intention. Environment-Behaviour Proceeding Journal, 3(7), Mar. 2018 (p.35-41)

Yuksel, A., \& Yuksel, F. (2002). Measurement of tourist satisfaction with restaurant services: a segment-based approach. Journal of Vacation Marketing, 9 (1), 52-68.

Yoo, S. A. (2012). Customer perceptions of restaurant cleanliness: A cross cultural study (Doctoral dissertation, Virginia Polytechnic Institute and State University).

Young, J. A., Clark, P. W., \& Mclntyre, F. S. (2007). An exploratory comparison of the casual dining experience. Journal of Foodservice Business Research, 10(3), 87-105. 